Piotr Jakubów ${ }^{1-4}$, Urszula Kościuczuk ${ }^{1,4}$, Juliusz Kosel ${ }^{1,4}$, Piotr Soroko ${ }^{1,5}$, Julia Kondracka ${ }^{1,6}$, Mariola Tałałaj ${ }^{2}$

'Pain Management Unit "Vitamed", Białystok, Poland

${ }^{2}$ Children and Adolescents Department od Anaesthesia and Intesive Care and Pain Therapy Unit, Białystok, Poland

${ }^{3}$ Department of Palliative Medicine, Medical University of Białystok

${ }^{4}$ Anaesthesia and Intensive Care Department, Medical University of Białystok, Bialystok, Poland

${ }^{5}$ Cardiology Department of the MSWiA (the Ministry of the Interior and Administration), Białystok, Poland

${ }^{6}$ Medical University of Gdańsk, Fourth-year Student of the Medical Faculty, Gdańsk, Poland

\title{
The role of pregabalin in neuropathic pain management in cancer patients
}

Abstract
Despite the wide availability of analgesics for prescription in cancer pain, including both opioid and non-opi-
oid medications, population studies have for many years demonstrated unadvisable pain management.
International analyses indicate inadequate use of opioid and adjuvant drugs per capita. At the same time,
patients complain about the accompanying pain, not treated effectively, especially in the course of cancer.
One of the many causes of cancer pain that is difficult to treat is the co-occurrence of neuropathic pain.
The article presents contemporary views on the treatment of neuropathic pain associated with cancer,
including the site of application of gabapentinoids in the treatment scheme.
Palliat Med Pract 2020; 14, 3: 175-182

Key words: cancer pain, neuropathic pain, pharmacotherapy, gabapentinoids, gabapentin, pregabalin

\section{Introduction}

Despite the wide availability of analgesics for pain management in cancer patients, including opioids and non-opioid analgesics, the results of population studies have shown ineffective pain treatment for many years [1, 2]. Poland is a country with low consumption of opioid and adjuvant analgesics per capita [2-4]. At the same time, patients, especially cancer ones, point to ineffective pain treatment $[5,6]$. One of the reasons for difficulties in pain treatment in cancer patients is a neuropathic pain component $[3,7]$.

\section{Diagnosis and clinical evaluation of neuropathic pain}

The diagnosis of neuropathic pain, both in cancer patients and in the course of other chronic diseases, is based on the anamnesis, physical examination and symptoms, particularly sensory disturbances [1, $8,9]$. The criteria allowing to determine a degree of certainty for neuropathic pain diagnosis $[10,11]$ were defined. The diagnostic criteria include the medical history of pain characteristics, neurological examination, neuroanatomical location and additional examinations $[12,13]$. On the basis of the above-mentioned criteria, the diagnosis of neuropathic pain may be definite, probable or possible. In diagnostics and monitoring, the Neuropathic Pain Scales (NPSs) play an auxiliary role $[14,15]$. In cancer patients, DN-4 (Douleur Neuropathique en 4 Questions) and NPQ (Neuropathic Pain Questionnaire) scales are most commonly used $[13,14]$.

Neuropathic pain has specific clinical presentation $[1,12,15]$. Patients describe pain as burning, piercing, tearing, blunt, stitching, crushing or tingling [6,

Address for correspondence:

Piotr Jakubów

"Vitamed" Pain Management Unit

ul. Konopnickiej 34, 15-586 Białystok, Poland

e-mail: jakubowpiotr@wp.pl

Palliative Medicine in Practice 2020; 14, 3, 175-182

Copyright (C) Via Medica, ISSN 2545-0425

DOI: $10.5603 /$ PMPI. 2020.0020 
$7,13]$. The pain occurs idiopathically or under the influence of physical and emotional stimuli. It can be very intense as well as recurrent or permanent. In cancer patients, neuropathic pain, compared to other types of pain, is characterised by worse response to analgesics $[16,17]$; however, it is not always the case with anticonvulsants and antidepressants [18, 19]. In the course of neuropathic pain, such conditions as allodynia (hyperaesthesia due to a stimulus which normally does not cause pain) and hyperalgesia (excessive pain sensation, disproportionate to the strength of the stimulus) and hypoalgesia, i.e. reduced pain sensation, are frequently observed $[10,13,20,21]$.

Apart from sensory disturbances, neuropathic pain is also characterised by cognitive dysfunctions (attention deficit disorders, short-term memory impairment) which cause mental lability and 'wait for pain' position $[10,20]$. Due to the persistent nature of neuropathic pain, which is often resistant to treatment, there is a fear of recurrence and intensification of pain, which hinders daily functioning and deteriorates the quality of life. Pain is accompanied by sleep problems, nervousness, chronic fatigue, lack of will and desire to treat the underlying disease [18]. Untreated neuropathic pain is characterised by insomnia, anxiety and depression caused by the accumulation of inflammatory cytokines due to stress, ejection of catecholamines, activation of the hypothalamo-pituitary axis and disturbances of central transmission, causing depression [20-22]. Analgesics are then used together with anxiolytic drugs and antidepressants. When neuropathic pain treatment in cancer patients is abandoned, due to the mental changes the patients tend to neglect anticancer and symptomatic treatment. The diagnosis of neuropathic pain in cancer patients does not differ from the diagnosis of neuropathy caused by other causes and it is based on detailed data from anamnesis, physical examination and diagnostic tests [23].

According to NeuPSIG [Neuropathic Pain Special Interest Group - International Association for the Study of Neuropathic Pain (IASP)], repetitive diagnostic schemes are recommended for the diagnosis of neuropathic pain [24]. Determination of the probability of neuropathic pain occurrence comprises data from the patient's clinical interview, the assessment of sensory descriptors suggesting the neuropathic mechanism of pain - e.g. triggering, twingeing, numbness and tingling - and location of those symptoms in the neuroanatomic system $[24,25]$. The clinical examination of sensory changes includes the assessment of touch sensation, the sense of vibration, prickling sensation, temperature sensitivity, using a swab, ampoule with cold and warm fluid or tuning fork in order to determine the extent of nervous system damage [26].
The definition of neuropathic pain developed by NeuPSIG indicates that it is the pain which is a direct consequence of a lesion or disease affecting the somatosensory nervous system, provoked by various causes, especially in cancer patients (Table 1) [16, 24, 27]. On this basis, neuropathic pain classification system (definite, probable and possible) was introduced. The distinction between neuropathic pain caused by cancer and other causes of that type of pain has not been made in the existing ICD classifications. Common for cancer-related as well as non-cancer-related pain, there was a symptomatic diagnosis of R52, which describes pain that is not classified elsewhere. The ICD-10 classification, introduced in 2019 in the United States, for the first time included the diagnosis of pain as a unit of neoplastic disease [28]. In the new ICD-10 CM classification (2020 version), published in 2019 by the American Medical Society, the G89.3 code concerning the occurrence of neoplasm-related pain was included. This record concerns both acute and chronic pain, including cancer-associated pain, pain due to malignancy (primary, secondary), tumor-associated pain and pain due to neoplastic disease. In the new version of the ICD-11 classification developed by WHO for various cultural parts of the world, including Europe, proposed to apply from 2021, an accurate international classification of chronic pain, including neuropathic pain and neoplasm-related pain was included as well [29, 30]. Pending the publication of new European diagnosis codes for neuropathic pain, the symptomatic diagnosis of code $\mathrm{R} 52$ pain remains valid. The causes of neuropathic pain in cancer patients are presented in Table 1.

\section{Pharmacotherapy of neuropathic pain}

In 2005, IASP developed recommendations for the pharmacological treatment of neuropathic pain based on Evidence-Based Medicine (EBM) principles. In 2006, the recommendations of the European Federation of Neurological Societies were published, which, in addition to the data concerning efficacy of medicines, include data on quality of life, the effect of treatment on sleep and the consequence of comorbidities. In subsequent years, numerous recommendations for treatment of neuropathic pain were published [1, $14,15,31]$. In 2007, recommendations for the neuropathic pain management in patients with chronic non-cancer-related pain were developed, which (with subsequent updates) include:

I. Symptomatic treatment should be preceded by a diagnosis of the cause of neuropathic pain and, if possible, followed by appropriate causal treatment. 
Table 1. Neuropathic pain syndromes in cancer patients

\begin{tabular}{|c|c|}
\hline $\begin{array}{l}\text { Directly } \\
\text { cancer-related } \\
\text { neuropathic } \\
\text { pain }\end{array}$ & $\begin{array}{l}\text { - Tumor-related or metastasis-related compression or infiltration of the skull or CNS structures, cer- } \\
\text { vical nerves in the course of cervical, jaw, palate, salivary gland cancers, metastatic lung, breast, } \\
\text { kidney, testicular, ovarian, prostate, melanoma cancers; childhood cancers: embryonic neuroma, } \\
\text { striated myosarcoma, Wilms' tumor } \\
\text { - Metastases or nerve infiltration due to lesions in bone structures, breast, lung, prostate, thyroid } \\
\text { and stomach cancers } \\
\text { - Painful neuralgias of the cranial and spinal nerves, glossopharyngeal neuralgia, trigeminal neu- } \\
\text { ralgia, radiculopathy } \\
\text { - Spinal cord compression caused by tumor growth or metastases } \\
\text { - Cancer dissemination into the subarachnoid space } \\
\text { - Non-localized cancer dissemination causing neuropathic pain } \\
\text { - Neuropathic pain due to weakened mechanisms of antinociception } \\
\text { Most common plexopathies in cancer patients: } \\
\text { - Cervical or brachial plexopathy } \\
\text { - Celiac plexopathy } \\
\text { - Lumbosacral plexopathy } \\
\text { - Neoplastic neuropathies } \\
\text { - Coccygodynia }\end{array}$ \\
\hline $\begin{array}{l}\text { Neuropathic } \\
\text { pain caused } \\
\text { by anticancer } \\
\text { treatment }\end{array}$ & $\begin{array}{l}\text { Persistent postoperative pain syndromes: neuropathic pain after thoracotomy, mastectomy, } \\
\text { abdominal surgery; phantom pain after limb amputation or amputation of other body structures } \\
\text { Neuropathic pain after radiotherapy: neuropathic pain as a result of radiotherapy of the brachial } \\
\text { plexus - radiation-induced neuropathy of brachial plexus, radiation myelopathy, painful postradi- } \\
\text { ation lymphoedema } \\
\text { Neuropathic pain after chemotherapy: platinum derivatives, vinca alkaloids, taxanes, bortezomib, } \\
\text { thalidomide; neuropathic pain after long-term hormonal therapy; neuropathic pain caused by an- } \\
\text { tiestrogens (tamoxifen) and aromatase inhibitors (anastrozole, letrozole, exemestane); neuropathic } \\
\text { pain after hematopoietic growth factors (HGF); neuropathic pain after administration of granulocyte } \\
\text { colony-stimulating factors (G-CSF); neuropathic pain as a result of mandibular necrosis caused by } \\
\text { treatment with bisphosphonates; neuropathic pain accompanying the immunomodulatory therapy }\end{array}$ \\
\hline $\begin{array}{l}\text { Indirectly } \\
\text { cancer-related } \\
\text { neuropathic } \\
\text { pain }\end{array}$ & $\begin{array}{l}\text { Hepes zoster infections as a cause of herpes neuralgia } \\
\text { Neurological complications in the course of sepsis } \\
\text { Infection-induced foot peripheral neuropathy } \\
\text { Neuropathic pain associated with immune deficiency without cancer location }\end{array}$ \\
\hline
\end{tabular}

II. Prior to treatment, comorbidities (including depression, heart or kidney diseases), which may be contraindications for treatment or require changes in the doses of analgesics, should be diagnosed.

III. Patients should be informed about the diagnosis and treatment plan as well as realistic goals and realistically expected efficacy of the therapy.

IV. Treatment of neuropathic pain should be performed according to current recommendations.

V. First-line medicines to treat neuropathic pain:

- Anticonvulsants: pregabalin or gabapentin

- Antidepressants: serotonin and norepinephrine reuptake inhibitors

VI. Second-line medicines:

- Tricyclic antidepressants (amitriptyline)

- Lidocaine applied topically

- Capsaicin applied topically

VII. Third-line medicines:

- Opioid analgesics or rotation, if previously applied.

VIII. Fourth-line medicines:

- Cannabinoids, methadone, carbamazepine (except for trigeminal neuralgia, where it is the first-line medicine) and other anticonvulsants.

For the treatment of neuropathic pain in cancer patients the procedure of choice is the use of opiod analgesics according to the WHO analgesic ladder. Opiods are therefore the first line of pharmacotherapy in cancer patients with moderate to severe neuropathic pain.

\section{Recommendations for the pharmacological treatment of neuropathic pain}

- If the first-line treatment is effective (pain reduction of at least $50 \%$ ), it should be continued.

- If the effeciency is not satisfactory, another firstline drug with a different mechanism of action should be added; if the first-line drug is not effective, it should be changed into another first-line drug.

- The lack of effeciency of first-line drugs, used alone or in combination (in appropriate doses), is an indication of therapy with second- and third- 
line drugs.

- For the treatment of neuropathic and difficult pain in cancer patients, analgesic adjuvants are added to opioids.

- Medicinal treatment should be complemented, if possible, by non-pharmacological one.

- The efficacy and tolerance (side effects) of treatment should be frequently assessed.

For the treatment of neuropathic pain in cancer patients, analgesic adjuvants are often (in more than $80 \%$ of patients) applied using additive synergy (an increase of the analgesic effect of drugs with different mechanisms of action) [32-35]. The treatment of neuropathic pain in cancer patients requires caution, as many drugs from different groups are applied: gabapentinoids (pregabalin, gabapentin), serotonin and norepinephrine reuptake inhibitors (duloxetine, venlafaxine), anticonvulsants (carbamazepine, oxcarbazepine, valproic acid), tricyclic antidepressants (amitriptyline), opioids, cannabinoids and topical medications (capsaicin, lidocaine) [36]. Muscle relaxants, anti-anxiety drugs, corticosteroids, anaesthetics (ketamine), intervention methods, physiotherapy and psychotherapy are also used [21, 37]. In patients with neuropathic pain, first-, second-, third- and fourth-line treatments have been distinguished.

Gabapentinoids are first-line drugs for the treatment of neuropathic pain in patients with non-cancer-related pain [38]. In the pharmacological treatment of trigeminal neuralgia, carbamazepine and its derivatives are still recommended as first-line drugs [39-41]. In the medicinal treatment of neuropathic pain, as an auxiliary agent, B vitamins are used in case of deficiency. Neuropathic pain management is multidirectional and also includes both non-pharmacological and interventional methods. In many cases, nerve blockades and neurolyses are used to inhibit pain transmission [41]. An important element of therapy is physiotherapy and improvement of patient's mobility, which significantly inhibit the disease progress $[22,24]$.

\section{Gabapentin}

In its chemical structure, gabapentin is similar to gamma-aminobutyric acid (GABA) (Fig. 2) [39]. The mechanism of action is different from that of other active substances interacting with GABA-ergic synapses: valproate, barbiturates, benzodiazepines, GABA transaminase inhibitors, GABA uptake inhibitors, GABA agonists and GABA prodrugs [40]. In vitro studies using labelled gabapentin described the peptide-binding site in brain tissue, i.a. within the new cortex and hippocampus, which may be associated with anticonvulsant and analgesic effects of gabapentin and its structural derivatives [40]. The binding site of gabapentin was identified within alpha-2/delta subunit of the voltage-gated calcium channels. Gabapentin does not bind to GABA-A, GABA-B, benzodiazepine, glutamate, glycine and $\mathrm{N}$-methyl-D-aspartate (NMDA) receptors.

In in vitro conditions, unlike other anticonvulsants (phenytoins, carbamazepine), gabapentin does not interact with sodium channels [39]. In experimental studies, gabapentin partially weakens reactions to the NMDA glutamate agonist, but only at concentrations above $100 \mu \mathrm{M}$, which are not achieved in in vivo conditions. Gabapentin slightly reduces the release of monoamine neurotransmitters in in vitro conditions. The administration of gabapentin increases GABA turnover in several areas of the brain in a similar way to sodium valproate, although in other regions. The significance of the described directions of gabapentin actions for the anticonvulsant effect remains undefined. Apart from the anticonvulsant effect, the analgesic effect in the treatment of neuropathic pain has been described in the characteristics of medicinal products and registered for some products to be used by health insurance patients in Poland.

The gabapentin dosage for peripheral neuropathic pain requires a gradual increase in doses. Treatment may be started with 300 mg per day or 900 mg per day in three equally divided doses. Then, depending on the body's individual response and treatment tolerance, the dose can be increased by $300 \mathrm{mg}$ per day, every 2-3 days, up to a maximum dose of $3,600 \mathrm{mg}$ per day. The minimum time needed to reach the dose of $1,800 \mathrm{mg}$ per day is 7 days, the dose of $2,400 \mathrm{mg}$ per day -14 days, 3,600 mg per day -21 days. In elderly patients and those with renal disease (or dialysis patients) it is necessary to modify the drug dose.

\section{Pregabalin}

Pregabalin is a relatively new drug active against stimulatory and inhibitory neurons [42]. The drug was synthesised in an American laboratory in 1990 as a successor to gabapentin. It should be noted that the Polish laboratory researcher, Ryszard Andruszkiewicz [43], contributed to the creation of this compound. Pregabalin is GABA derivative and analogue, but it works differently from GABA-ergic drugs. Its structure resembles $\alpha$-amino acids naturally occurring in CNS - L-leucine and L-isoleucine. A chemical structure of the drug slightly differs from gabapentin (Fig. 1). Pregabalin acts by inhibiting some calcium channels, without being a GABA receptor agonist [44]. The drug is a ligand depending on the voltage of calcium channels (VGCC, voltage-gated calcium channels) and 
<smiles>CC(C)C[C@H](CN)CC(=O)O</smiles>

Figure 1. Structural patterns of gabapentinoids. A. Pregabalin. B. Gabapentin. Pregabalin is characterised by a simple chemical structure with fewer carbon atoms in lateral electrode placement.

a VGCC inhibitor containing $\alpha 2 \delta-1$ and $\alpha 2 \delta-2$ subunits. Although pregabalin is GABA analogue, it does not bind to GABA receptors, nor convert to GABA or another GABA receptor agonist in vivo, nor directly modulate GABA transport or metabolism. Pregabalin increases L-glutamic acid decarboxylase (GAD), the enzyme responsible for GABA synthesis, and thus may show indirect GABAergic effects [45].

The effect of pregabalin on the voltage-gated calcium channels (VGCCS) is responsible for anticonvulsant, analgesic and anti-anxiety effects. Compared to gabapentin, pregabalin shows higher affinity to VGCCs, 4 times stronger analgesic effect and, in experimental animal studies, 10 times stronger anticonvulsant effect [46]. The drug was registered in 2004 in Europe and the United States for the supportive treatment of partial epileptic seizures in adults, the treatment of post-herpetic neuralgia, neuropathic pain (in the clinical presentation - burning, ripping, acute and penetrating pain), peripheral diabetic polyneuropathy, as well as the treatment of generalised anxiety disorders [47].

Pregabalin is recommended by the European Federation of Neurological Societies as a first-line drug in the treatment of diabetic-related neuropathic pain, post-herpetic neuralgia and central neuropathic pain [48]. It has been registered for the above-mentioned indications, but can also be used to treat other types of neuropathic pain. Pregabalin reduces excessive neuronal excitability, relieves neuropathic pain after reaching stable plasma levels after only a few days [49]. Because of its simple molecular structure, unlike gabapentin, it is effective both in treatment of central neuropathic pain and peripheral neuropathies in the course of spinal diseases, arteriosclerosis, haematological, rheumatological and infectious diseases - Lyme disease and HIV (human immunodeficiency virus). It is recommended to use the drug in iatrogenic neuropathies, including postoperative and drug-induced ones [50]. The drug can be used in the pain management in the course of neuropathy caused by cytostatics administered in the treatment of cancer, anti-TB and anti-epileptic drugs, as well as in lead poisoning and alcohol one, and in nutrition-related deficiency [49].

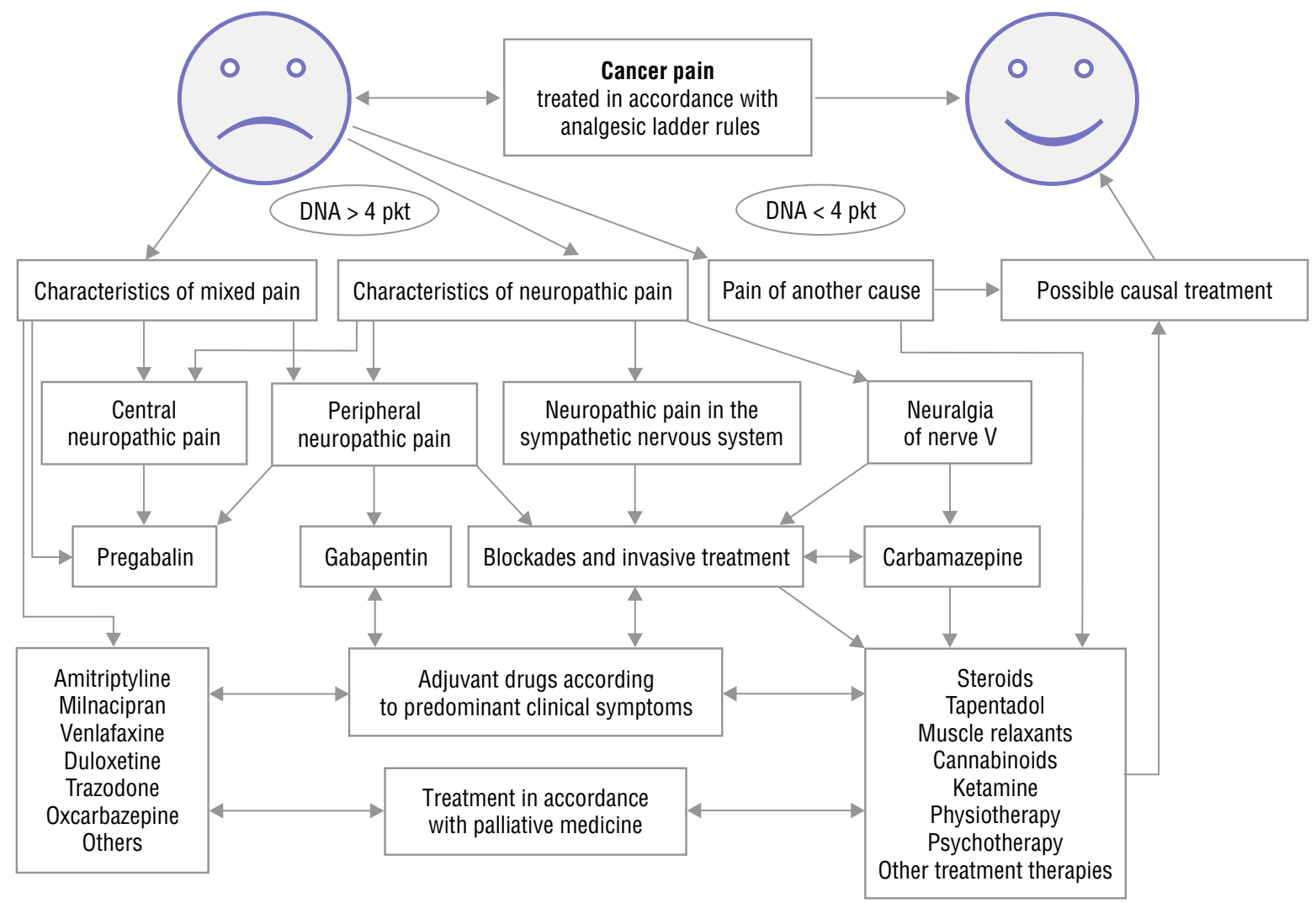

Figure 2. Algorithm for the diagnosis and treatment of neuropathic pain in cancer patients 
The bioavailability of pregabalin after oral administration is over $90 \%$, in the range of clinical doses of 50-600 mg per day. The bioavailability of pregabalin is not significantly affected by food intake. The drug is metabolized to a small extent and approximately $98 \%$ of the drug is excreted with urine in an unchanged form . As pregabalin clearance is directly proportional to creatinine clearance, doses in patients with renal impairment should be reduced individually.

Treatment of neuropathic pain can be started with a dose of $150 \mathrm{mg}$ per day, administered in two or - less frequently - three divided doses. Depending on the patient's individual reaction and treatment tolerance, after 3-7 days the dose may be increased up to $300 \mathrm{mg}$ per day, and then, depending on the need, after another 7 days, up to the maximum dose of $600 \mathrm{mg}$ per day $[35,50]$. In patients with renal failure and older patients, doses may be lower, usually initially 25-75 mg per day.

The use of pregabalin for neuropathic pain in cancer patients is recommended in several health systems, also in Poland $[28,31,49]$. There is no evidence of the drug efficiency in migraine prevention, although such use has also been described [29]. The potential use of pregabalin in the prevention of persistent pain after surgical procedures is hopeful. Pregabalin is used, particularly when other methods are ineffective, to treat partial epileptic seizures in adults, which are (or are not) secondary generalised. Treatment can be started from a dose of $150 \mathrm{mg}$ per day, administered in two or three divided doses, gradually increased, depending on the individual reaction and treatment tolerance, up to $300 \mathrm{mg}$ per day or up to a maximum dose of $600 \mathrm{mg}$ per day.

The attempts to use pregabalin in alcohol dependence, especially in withdrawal syndromes and accompanying convulsions, are very interesting [46]. The evidence in favour of the treatment of alcohol dependence is limited, while in the withdrawal syndrome it is used successfully, although the indication is not covered by the drug registration. Pregabalin is also effective and safe in the treatment of generalised anxiety disorders. The World Federation of Biological Psychology recommends pregabalin as one of the methods of treatment for generalised anxiety disorders, as well as first-line treatment of obsessive-compulsive disorders and post-traumatic stress disorder. The anxiolytic effect is similar to that of benzodiazepines, with lower risk of dependence development [46]. In addition to the treatment of neuropathic pain and generalised anxiety syndrome in adults, off-label use of pregabalin includes fibromyalgia, social anxiety, alcohol withdrawal syndrome and anxiety accompanying migraine attacks with aura [24].
The anxiolytic effect of pregabalin occurs after 7 days of treatment and is similarly effective as lorazepam, alprazolam and venlafaxine, but pregabalin is more effective in treating psychosomatic anxiety symptoms. Long-term studies have shown constant efficacy without the development of tolerance and, in contrast to benzodiazepines, a beneficial effect on sleep architecture, characterised by increased slowwave sleep. Compared to benzodiazepines, pregabalin causes less cognitive and psychomotor dysfunction and low risk of addiction. A significant adverse interaction occurs between pregabalin and lorazepam, which occurs at the concatenation level and causes a significant increase in sedation. In generalised anxiety disorders, the dose of $150 \mathrm{mg}$ once a day in the evening is recommended [51]. The therapeutic dose is $150-600 \mathrm{mg}$ per day, administered in two or three divided doses. The reaction to treatment and the need for its continuation should be regularly assessed.

Adverse effects associated with the use of pregabalin most frequently include dizziness and drowsiness. Approximately $1-10 \%$ of patients report xerostomia, increased appetite, weakness, blurred vision, mental confusion, attention deficit and motor coordination disorders, constipation, peripheral edema, reduced alcohol tolerance. As many as $0.1-1 \%$ of patients develop depression, lethargy, agitation, hallucinations, myoclonus, hyposensitivity, hypersensitivity, tachycardia, hypersalivation, hypoglycemia, perspiration, redness, rash, muscle pain, dysuria and thrombocytopenia [52].

After sudden withdrawal of pregabalin, insomnia, headaches, nausea, anxiety, diarrhoea and flu-like symptoms may occur. The Food and Drug Administration (FDA) determined that the substance dependence profile of pregabalin, as measured by a patient' physical withdrawal checklist, was quantitatively less than benzodiazepine. While taking pregabalin the symptoms of overdose may intensify in patients with renal failure as a result of gradual accumulation of the drug [52]. An acute overdose may manifest itself as drowsiness, tachycardia and hypertension. The proposed algorithm of the use of pregabalin and gabapentin in the treatment of neuropathic pain in cancer patients based on current recommendations is presented in Figure 2.

\section{Summary}

Opioid analgesics play an essential role in the treatment of pain in cancer patients, and analgesic adjuvants are added to opioids in the absence of satisfactory analgesia. It is important to adapt the treatment to somatic and mental symptoms. The ther- 
apeutic treatment is dependent on the type of pain (neuropathic pain, mixed pain caused e.g. by bone metastases) and the occurrence of other symptoms (depression, anxiety). In cancer patients, the basic principle is treatment according to the WHO three-stage analgesic ladder, and the diagnosis of a neuropathic pain component is an indication to consider coanalgesic in the absence of opioid effect. Pregabalin and gabapentin are first-line drugs for the treatment of neuropathic pain in patients with non-cancer-related pain, whereas in cancer patients they can be added to opioids in the absence of satisfactory analgesia when using opioid analgesics alone.

\section{Conflict of interests}

The authors declare that there is no conflict of interest.

\section{Funding}

This study has no funding.

\section{References}

1. Caraceni A, Hanks G, Kaasa S, et al. Use of opioid analgesics in the treatment of cancer pain: evidence-based recommendations from the EAPC. The Lancet Oncology. 2012; 13(2): e58-e68, doi: 10.1016/s1470-2045(12)70040-2.

2. Edwards HL, Mulvey MR, Bennett MI. Cancer-Related Neuropathic Pain. Cancers (Basel). 2019; 11(3), doi: 10.3390/cancers11030373, indexed in Pubmed: 30884837.

3. Arias-Casais N, Garralda E, Rhee JY, De Li, Pons JJ, Clark D. EAPC Atlas of palliative care in Europe 2019. Vilvoorde: EAPC Press 2019.

4. Ciałkowska-Rysz A, Dzierżanowski T. Podstawowe zasady farmakoterapii bólu u chorych na nowotwory i inne przewlekłe, postępujące, zagrażające życiu choroby. PalliativeMedicine. 2014; 1: 1-6.

5. Dzierżanowski T, Ciałkowska-Rysz A. Ból neuropatyczny u pacjentów objętych opieką paliatywną. Med Paliat. 2010; 2: 57-66.

6. Leppert W. Rola analgetyków opioidowych w leczeniu bólu neuropatycznego $u$ chorych na nowotwory. Medycyna Paliat Prakt. 2014; 8(2): 81-84.

7. Zajączkowska R, Wordliczek J, Leppert W. Mechanizmy i zespoły bólu neuropatycznego u chorych na nowotwór. Med Paliat Prakt. 2014; 8(2): 66-73.

8. Sumitani M, Sakai T, Matsuda $Y$, et al. Executive summary of the Clinical Guidelines of Pharmacotherapy for Neuropathic Pain: second edition by the Japanese Society of Pain Clinicians. J Anesth. 2018; 32(3): 463-478, doi: 10.1007/s00540018-2501-0, indexed in Pubmed: 29737410.

9. Finnerup NB, Attal N, Haroutounian S, et al. Pharmacotherapy for neuropathic pain in adults: a systematic review and meta-analysis. Lancet Neurol. 2015; 14(2): 162-173, doi: 10.1016/S1474-4422(14)70251-0, indexed in Pubmed: 25575710.

10. Baron R, Maier C, Attal N, et al. Peripheral neuropathic pain: a mechanism-related organizing principle based on sensory profiles. Pain. 2017; 158(2): 261-272, doi: 10.1097/j. pain. 0000000000000753 , indexed in Pubmed: 27893485.

11. Janecki M. Przegląd narzędzi służących do oceny bólu neuropatycznego. Med Paliat Prakt. 2014; 8(2): 74-77.
12. Mathieson $S$, Maher CG, Terwee CB, et al. Neuropathic pain screening questionnaires have limited measurement properties. A systematic review. J Clin Epidemiol. 2015; 68(8): 957-966, doi: 10.1016/j.jclinepi.2015.03.010, indexed in Pubmed: 25895961.

13. Boland EG, Mulvey MR, Bennett MI. Classification of neuropathic pain in cancer patients. Curr Opin Support Palliat Care. 2015; 9(2): 112-115, doi: 10.1097/SPC.0000000000000136, indexed in Pubmed: 25923341.

14. Chaparro LE, Wiffen PJ, Moore RA, et al. Combination pharmacotherapy for the treatment of neuropathic pain in adults. Cochrane Database Syst Rev. 2012(7): CD008943, doi: 10.1002/14651858.CD008943.pub2, indexed in Pubmed: 22786518.

15. Szczudlik A, Dobrogowski J, Wordliczek J, et al. Diagnosis and Management of Neuropathic Pain: Review of Literature and Recommendations of the Polish Association for the Study of Pain and the Polish Neurological Society - Part One. Ból. 2014; 15(3): 8-21, doi: 10.5604/1640324x.1117109.

16. Szczudlik A, et al. Rozpoznanie i leczenie bólu neuropatycznego część 2: przegląd piśmiennictwa i zalecenia Polskiego Towarzystwa Badania Bólu i Towarzystwa Neurologicznego. Ból 2014; 15(2): 8-18. PTBB. (www.ptbb.pl).

17. Ciałkowska-Rysz A, Dzierżanowski T. Topical morphine for treatment of cancer-related painful mucosal and cutaneous lesions: a double-blind, placebo-controlled cross-over clinical trial. Arch Med Sci. 2019; 15(1): 146-151, doi: 10.5114/aoms.2018.72566, indexed in Pubmed: 30697265.

18. Wordliczek J, Zajączkowska R, Leppert W. Pharmacotherapy of neuropathic pain. Med Paliat Prakt. 2017; 11(2): 61-73.

19. Ciałkowska-Rysz A, Dzierżanowski T. Ból neuropatyczny u pacjenta z naciekiem nowotworowym okolicy lędźwiowo-krzyżowej - opis przypadku. Med Paliat. 2012; 4: 229-231.

20. Moulin D, Boulanger A, Clark AJ, et al. Canadian Pain Society. Pharmacological management of chronic neuropathic pain: revised consensus statement from the Canadian Pain Society. Pain Res Manag. 2014; 19(6): 328-335, doi: 10.1155/2014/754693, indexed in Pubmed: 25479151.

21. Fallon M, Giusti R, Aielli F, et al. ESMO Guidelines Committee. Electronic address: clinicalguidelines@esmo.org, ESMO Guidelines Committee. Management of cancer pain in adult patients: ESMO Clinical Practice Guidelines. Ann Oncol. 2018; 29(Suppl 4): iv166-iv191, doi: 10.1093/annonc/mdy152, indexed in Pubmed: 30052758.

22. Rayment $\mathrm{C}$, Hjermstad MJ, Aass N, et al. European Palliative Care Research Collaborative (EPCRC). Neuropathic cancer pain: prevalence, severity, analgesics and impact from the European Palliative Care Research Collaborative-Computerised Symptom Assessment study. Palliat Med. 2013; 27(8): 714-721, doi: 10.1177/0269216312464408, indexed in Pubmed: 23175513.

23. Attal N. Neuropathic Pain Special Interest Group of the International Association for the Study of Pain. Management of neuropathic cancer pain. Ann Oncol. 2010; 21(5): 1134-1135, doi: 10.1093/annonc/mdq031, indexed in Pubmed: 20147740.

24. Oosterling A, te Boveldt N, Verhagen C, et al. Neuropathic Pain Components in Patients with Cancer: Prevalence, Treatment, and Interference with Daily Activities. Pain Pract. 2016; 16(4): 413-421, doi: 10.1111/papr.12291, indexed in Pubmed: 25857631.

25. Bennett MI, Kaasa S, Barke A, et al. IASP Taskforce for the Classification of Chronic Pain. The IASP classification of chronic pain for ICD-11: chronic cancer-relat- 
ed pain. Pain. 2019; 160(1): 38-44, doi: 10.1097/j. pain. 0000000000001363 , indexed in Pubmed: 30586069.

26. Finnerup NB, Haroutounian S, Kamerman P, et al. Neuropathic pain: an updated grading system for research and clinical practice. Pain. 2016; 157(8): 1599-1606, doi: 10.1097/j. pain. 0000000000000492 , indexed in Pubmed: 27115670.

27. The International Classification of Diseases, Tenth Revision, Clinical Modification. 2020 edition of ICD-10-CM, American Medical Association 2020. https://www.cdc. gov/nchs/icd/icd $10 \mathrm{~cm} . \mathrm{htm}$. (The 2020 edition of ICD10-CM became effective on 1 October 2019).

28. Scholz J, Finnerup NB, Attal N, et al. Classification Committee of the Neuropathic Pain Special Interest Group (NeuPSIG). The IASP classification of chronic pain for ICD-11: chronic neuropathic pain. Pain. 2019; 160(1): 53-59, doi: 10.1097/j.pain.0000000000001365, indexed in Pubmed: 30586071.

29. Bennett MI, Kaasa S, Barke A, et al. IASP Taskforce for the Classification of Chronic Pain. The IASP classification of chronic pain for ICD-11: chronic cancer-related pain. Pain. 2019; 160(1): 38-44, doi: 10.1097/j. pain. 0000000000001363 , indexed in Pubmed: 30586069.

30. Finnerup NB, Sindrup SH, Jensen TS. The evidence for pharmacological treatment of neuropathic pain. Pain. 2010; 150(3): 573-581, doi: 10.1016/j.pain.2010.06.019, indexed in Pubmed: 20705215.

31. Yoon SoY, Oh J. Neuropathic cancer pain: prevalence, pathophysiology, and management. Korean J Intern Med. 2018; 33(6): 1058-1069, doi: 10.3904/kjim.2018.162, indexed in Pubmed: 29929349.

32. Mercadante S, Klepstad P, Kurita GP, et al. European Palliative Care Research Collaborative (EPCRC). Sympathetic blocks for visceral cancer pain management: A systematic review and EAPC recommendations. Crit Rev Oncol Hematol. 2015; 96(3): 577-583, doi: 10.1016/j.critrevonc.2015.07.014, indexed in Pubmed: 26297518.

33. Colloca L, Ludman T, Bouhassira D, et al. Neuropathic pain. Nat Rev Dis Primers. 2017; 3: 17002, doi: 10.1038/nrdp.2017.2, indexed in Pubmed: 28205574.

34. Kane CM, Mulvey MR, Wright S, et al. Opioids combined with antidepressants or antiepileptic drugs for cancer pain: Systematic review and meta-analysis. Palliat Med. 2018; 32(1): 276-286, doi: 10.1177/0269216317711826, indexed in Pubmed: 28604172.

35. Woroń J, Adamczyk A, Malec-Milewska M, et al. Stosowanie koanalgetyków u pacjentów z bólem neuropatycznym w przebiegu choroby nowotworowej. Med Paliat Prakt 2014; 8. 2014; 8(2): 85-90.

36. Kotlinska-Lemieszek A, Klepstad P, Haugen DF. Clinically significant drug-drug interactions involving opioid analgesics used for pain treatment in patients with cancer: a systematic review. Drug Des Devel Ther. 2015; 9: 5255-5267, doi: 10.2147/DDDT.S86983, indexed in Pubmed: 26396499.

37. Mercadante S, Caruselli A, Casuccio A. The use of ketamine in a palliative-supportive care unit: a retrospective analysis. Ann Palliat Med. 2018; 7(2): 205-210, doi: 10.21037/apm.2018.01.01, indexed in Pubmed: 29764182.

38. Uchitel OD, Di Guilmi MN, Urbano FJ, et al. Acute modulation of calcium currents and synaptic transmission by gabapentinoids. Channels (Austin). 2010; 4(6): 490-496, doi: 10.4161/chan.4.6.12864, indexed in Pubmed: 21150315.

39. Jordan RI, Mulvey MR, Bennett MI. A critical appraisal of gabapentinoids for pain in cancer patients. Curr Opin Support Palliat Care. 2018; 12(2): 108-117, doi:
10.1097/SPC.0000000000000337, indexed in Pubmed: 29465469.

40. Slee A, Nazareth I, Bondaronek P, et al. Pharmacological treatments for generalised anxiety disorder: a systematic review and network meta-analysis. Lancet. 2019; 393(10173): 768-777, doi: 10.1016/50140-6736(18)31793-8, indexed in Pubmed: 30712879.

41. Wordliczek J, Kotlińska-Lemieszek A, Leppert W, et al. Farmakoterapia bólu u chorych na nowotwory - zalecenia Polskiego Towarzystwa Badania Bólu, Polskiego Towarzystwa Medycyny Paliatywnej, Polskiego Towarzystwa Onkologicznego, Polskiego Towarzystwa Medycyny Rodzinnej i Polskiego Towarzystwa Anestezjologii i Intensywnej Terapii. Pain. 2017; 18(3): 11-53.

42. Andruszkiewicz R, Silverman RB. 4-Amino-3-alkylbutanoic acids as substrates for gamma-aminobutyric acid aminotransferase. J Biol Chem. 1990; 265(36): 22288-22291, indexed in Pubmed: 2266125.

43. Linde M, Mulleners W, Chronicle E, et al. Gabapentin or pregabalin for the prophylaxis of episodic migraine in adults. Cochrane Database of Systematic Reviews. 2013; 6(6): CD010609, doi: 10.1002/14651858.cd010609.

44. Bennett MI, Laird B, van Litsenburg C, et al. Pregabalin for the management of neuropathic pain in adults with cancer: a systematic review of the literature. Pain Med. 2013; 14(11): 1681-1688, doi: 10.1111/pme.12212, indexed in Pubmed: 23915361.

45. Bockbrader HN, Wesche D, Miller R, et al. A comparison of the pharmacokinetics and pharmacodynamics of pregabalin and gabapentin. Clin Pharmacokinet. 2010; 49(10): 661-669, doi: 10.2165/11536200-000000000-00000, indexed in Pubmed: 20818832.

46. Frampton JE. Pregabalin: a review of its use in adults with generalized anxiety disorder. CNS Drugs. 2014; 28(9): 835-854, doi: 10.1007/s40263-014-0192-0, indexed in Pubmed: 25149863.

47. Wensel TM, Powe KW, Cates ME. Pregabalin for the treatment of generalized anxiety disorder. Ann Pharmacother. 2012; 46(3): 424-429, doi: 10.1345/aph.1Q405, indexed in Pubmed: 22395254.

48. Derry $S$, Bell RF, Straube $S$, et al. Pregabalin for neuropathic pain in adults. Cochrane Database Syst Rev. 2019; 1: CD007076, doi: 10.1002/14651858.CD007076.pub3, indexed in Pubmed: 30673120.

49. Onakpoya IJ, Thomas ET, Lee JJ, et al. Benefits and harms of pregabalin in the management of neuropathic pain: a rapid review and meta-analysis of randomised clinical trials. BMJ Open. 2019; 9(1): e023600, doi: 10.1136/bmjopen-2018-023600, indexed in Pubmed: 30670513.

50. de Andrade DC, Jacobsen Teixeira M, Galhardoni R, et al. PreOx Workgroup. Pregabalin for the Prevention of Oxaliplatin-Induced Painful Neuropathy: A Randomized, Double-Blind Trial. Oncologist. 2017; 22(10): 1154-e105, doi: 10.1634/theoncologist.2017-0235, indexed in Pubmed: 28652279.

51. Gül ŞK, Tepetam H, Gül HL. Duloxetine and pregabalin in neuropathic pain of lung cancer patients. Brain Behav. 2020; 10(3): e01527, doi: 10.1002/brb3.1527, indexed in Pubmed: 31967742.

52. Yajima R, Matsumoto $K$, Ise $Y$, et al. Pregabalin prescription for terminally ill cancer patients receiving specialist palliative care in an acute hospital. J Pharm Health Care Sci. 2016; 2: 29, doi: 10.1186/s40780-016-0063-6, indexed in Pubmed: 27826454. 
Piotr Jakubów ${ }^{1-4}$, Urszula Kościuczuk ${ }^{1,4}$, Juliusz Kosel ${ }^{1,4}$, Piotr Soroko ${ }^{1,5}$, Julia Kondracka ${ }^{1,6}$, Mariola Tałałaj ${ }^{2}$

'Poradnia Leczenia Bólu „Vitamed”, Białystok, Polska

${ }^{2}$ Klinika Anestezjologii i Intensywnej Terapii Dzieci i Młodzieży z Pododdziałem Pooperacyjnym i Leczenia Bólu,

Uniwersytet Medyczny w Białymstoku

${ }^{3}$ Zakład Medycyny Paliatywnej, Uniwersytet Medyczny w Białymstoku

${ }^{4}$ Klinika Anestezjologii i Intensywnej Terapii, Uniwersytet Medyczny w Białymstoku

${ }^{5}$ Oddział Kardiologii Szpitala MSWIA, Białymstok, Polska

${ }^{6}$ Uniwersytet Medyczny w Gdańsku, studentka V roku, Gdańsk, Polska

\section{Rola pregabaliny w leczeniu bólu neuropatycznego u chorych}

\section{na nowotwory}

Artykuł jest tłumaczeniem pracy: Jakubów P., Kościuczuk U., Kosel J., Soroko P., Kondracka J., Tałałaj M., The role of pregabalin in neuropathic pain management in cancer patients. Palliat. Med. Pract. 2020 tom 14, nr 3: 175-182.

Należy cytować wersję pierwotną.

\section{Streszczenie}

Pomimo szerokiej dostępności do ordynacji leków przeciwbólowych możliwych do zastosowania w bólu nowotworowym, w tym zarówno leków opioidowych, jak i nieopioidowych, wyniki badań populacyjnych od wielu lat wskazują nieadektwatne leczenie bólu. W analizach miedzynarodowych wskazuje się nieadekwatne zużycie leków opioidowych oraz leków adjuwantowych w przeliczeniu na jednego mieszkańca. Równocześnie pacjenci wskazują na towarzyszący, nieskutecznie leczony ból, szczególnie w przebiegu choroby nowotworowej. Jedną z wielu przyczyn trudnego do leczenia bólu nowotworowego jest współwystępowanie bólu neuropatycznego. W artykule przedstawiono współczesne poglądy na leczenie bólu neuropatycznego towarzyszącego chorobie nowotworowej, w tym miejsce zastosowania gabapentynoidów w schemacie leczenia.

Palliat Med Pract 2020; 14, 3: 183-191

Słowa kluczowe: ból nowotworowy, ból neuropatyczny, farmakoterapia, gabapentynoidy, gabapentyna, pregabalina

\section{Wstęp}

Pomimo szerokiej dostępności leków przeciwbólowych możliwych do zastosowania w terapii bólu u chorych na nowotwory, w tym opioidów i analgetyków nieopioidowych, od wielu lat wyniki badań populacyjnych wskazują na nieskuteczne leczenie bólu [1, 2].
Polska jest krajem o niewielkim zużyciu analgetyków opioidowych i adjuwantów analgetycznych w przeliczeniu na jednego mieszkańca [2-4]. Równocześnie chorzy, zwłaszcza na nowotwory, wskazują na nieskutecznie leczony ból $[5,6]$. Jedną z przyczyn trudności w leczeniu bólu u chorych na nowotwory jest występowanie komponentu bólu neuropatycznego [3, 7].

\footnotetext{
Adres do korespondencji:

Piotr Jakubów

Poradnia Leczenia Bólu Vitamed

ul.Konopnickiej 34, 15-586 Białystok, Polska

e-mai: jakubowpiotr@wp.pl 


\section{Rozpoznanie i ocena kliniczna bólu neuropatycznego}

Rozpoznanie bólu neuropatycznego, zarówno u chorych na nowotwory, jak i w przebiegu innych chorób przewlekłych, jest dokonywane na podstawie wywiadu, badania przedmiotowego i objawów, zwłaszcza zaburzeń czucia [1, 8, 9]. Zdefiniowano kryteria, pozwalające na ustalenie stopnia pewności rozpoznania bólu neuropatycznego [10,11]. Kryteriami rozpoznania jest wywiad odnośnie charakterystyki bólu, badanie neurologiczne, lokalizacja neuroanatomiczna i badania dodatkowe $[12,13]$. Na podstawie powyższych kryteriów rozpoznanie bólu neuropatycznego może być pewne, prawdopodobne lub możliwe. W diagnostyce i monitorowaniu pomocniczą rolę odgrywają skale oceny bólu neuropatycznego [14, 15]. $\mathrm{U}$ chorych na nowotwory najczęściej stosowana jest skala DN-4 (Douleur Neuropathique en 4 Questions) i NPQ (The Neuropathic Pain Questionnaire) [13, 14].

Ból neuropatyczny cechuje charakterystyczny obraz kliniczny $[1,12,15]$. Pacjenci określają ból, jako piekący, palący, przeszywający, rozrywający, tępy, kłujący lub uciskający, z mrowienieniami $[6,7,13]$. Ból pojawia się samoistnie, bądź pod wpływem bodźca fizycznego i emocjonalnego, może mieć bardzo silne natężenie i napadowy lub stały charakter. $U$ chorych na nowotwory ból neuropatyczny, w porównaniu z innymi rodzajami bólu, cechuje gorsza odpowiedź na leki przeciwbólowe [16, 17], jednak zazwczaj odpowiada na leki przeciwdrgawkowe i przeciwdepresyjne [18, 19]. W przebiegu bólu neuropatycznego często obserwuje się allodynię (przeczulicę na skutek działania bodźca, który w normalnych warunkach nie powoduje bólu) i hiperalgezję (nadmierne odczuwanie bólu, nieproporcjonalne do siły bodźca) lub hipoalgezję, czyli zmniejszone odczuwanie bólu [10, 13, 20, 21].

Cechą bólu neuropatycznego, oprócz zaburzeń czucia, są również zaburzenia funkcji poznawczych (zaburzenia uwagi, pamięci krótkoterminowej), które powodują labilność psychiczną i postawę oczekiwania na ból $[10,20]$. Ze względu na uporczywy i często oporny na leczenie charakter bólu neuropatycznego, następuje obawa przed nawrotami i nasileniem bólu, co utrudnia codzienne funkcjonowanie i pogarsza jakość życia. Bólowi towarzyszą problemy ze snem, nerwowość, przewlekłe zmęczenie, brak woli i chęci leczenia choroby podstawowej [18]. W nieleczonym bólu neuropatycznym występują bezsenność, lęk i depresja spowodowane nagromadzeniem cytokin zapalnych przez stres, wyrzut amin katecholowych, aktywacją osi podwzgórzowo-przysadkowej i zaburzeniami transmisji ośrodkowej, powodujące depresję [20-22]. Leki przeciwbólowe są wówczas stosowane razem z lekami przeciwlękowymi i przeciwdepresyjnymi. Przy zaniechaniu leczenia bólu neuropatycznego u chorych na nowotwory zmiany psychiczne powodują, że pacjenci zaniedbują leczenie przeciwnowotworowe i objawowe. Rozpoznanie bólu neuropatycznego u chorych na nowotwory nie różni się od diagnozy neuropatii spowodowanej innymi przyczynami i opiera się na szczegółowych danych z wywiadu i badania przedmiotowego oraz testach diagnostycznych [23].

Według NeuPSIG (Neuropathic Pain Special Interest Group - Międzynarodowe Stowarzyszenie Badań Bólu Neuropatycznego w ramach IASP) w celu rozpoznania bólu neuropatycznego zalecane są powtarzalne schematy diagnostyczne [24]. Ustalenie prawdopdobieństwa wystąpienia bólu neuropatycznego obejmuje dane z wywiadu klinicznego pacjenta, ocenę tak zwanych deskryptorów sensorycznych sugerujących mechanizm neuropatyczny bólu, na przykład strzelanie, kłucie, drętwienie i mrowienie i lokalizację wymienionych objawów w układzie neuroanatomicznym $[24,25]$. Badanie kliniczne zmian sensorycznych obejmuje ocenę dotyku, wibracji, ukłucia, zimna i ciepła za pomocą wacika, ampułki z zimnym i ciepłym płynem lub kamertonu, w celu określenia rozległości uszkodzenia układu nerwowego [26].

Definicja bólu neuropatycznego opracowana przez NeuPSIG wskazuje, że jest to ból będący bezpośrednią konsekwencją zmiany lub choroby wpływającej na układ nerwowy somatosensoryczny, wywołany przez różne przyczyny, zwłaszcza u chorych na nowotwory (tab. 1) [16, 24, 27]. Na tej podstawie wprowadzono system klasyfikacji bólu neuropatycznego możliwego, prawdopodobnego i pewnego. W dotychczasowych klasyfikacjach ICD nie rozróżniano bólu neuropatycznego spowodowanego chorobą nowotworową od innych przyczyn tego rodzaju bólu. Wspólnie dla bólu związanego z chorobą nowotworową, jak również niezwiązanego z chorobą nowotworową, przyjmowano rozpoznanie objawowe R52, które opisuje ból niesklasyfikowany gdzie indziej. We wprowadzonej w 2019 roku w Stanach Zjednoczonych klasyfikacji ICD-10 po raz pierwszy ujęto rozpoznanie bólu jako jednostki w chorobie nowotworowej [28]. W nowej klasyfikacji ICD-10 CM w wersji 2020, opublikowanej w 2019 roku przez Amerykańskie Towarzystwo Medyczne ujęto zapis kodu G89.3 o występowaniu bólu związanego z chorobą nowotworową. Zapis ten dotyczy zarówno bólu ostrego, jak i przewlekłego, w tym bólu neuropatycznego związanego z chorobą nowotworową i opisywany jest jako ból związany z chorobą nowotworową. Również w nowej wersji ICD-11 opracowanej przez Światową Organizację Zdrowia (WHO, World Health Organization) dla różnych kulturowo części świata, w tym Europy, proponowanej do zas- 
Tabela 1. Zespoły bólu neuropatycznego u chorych na nowotwory

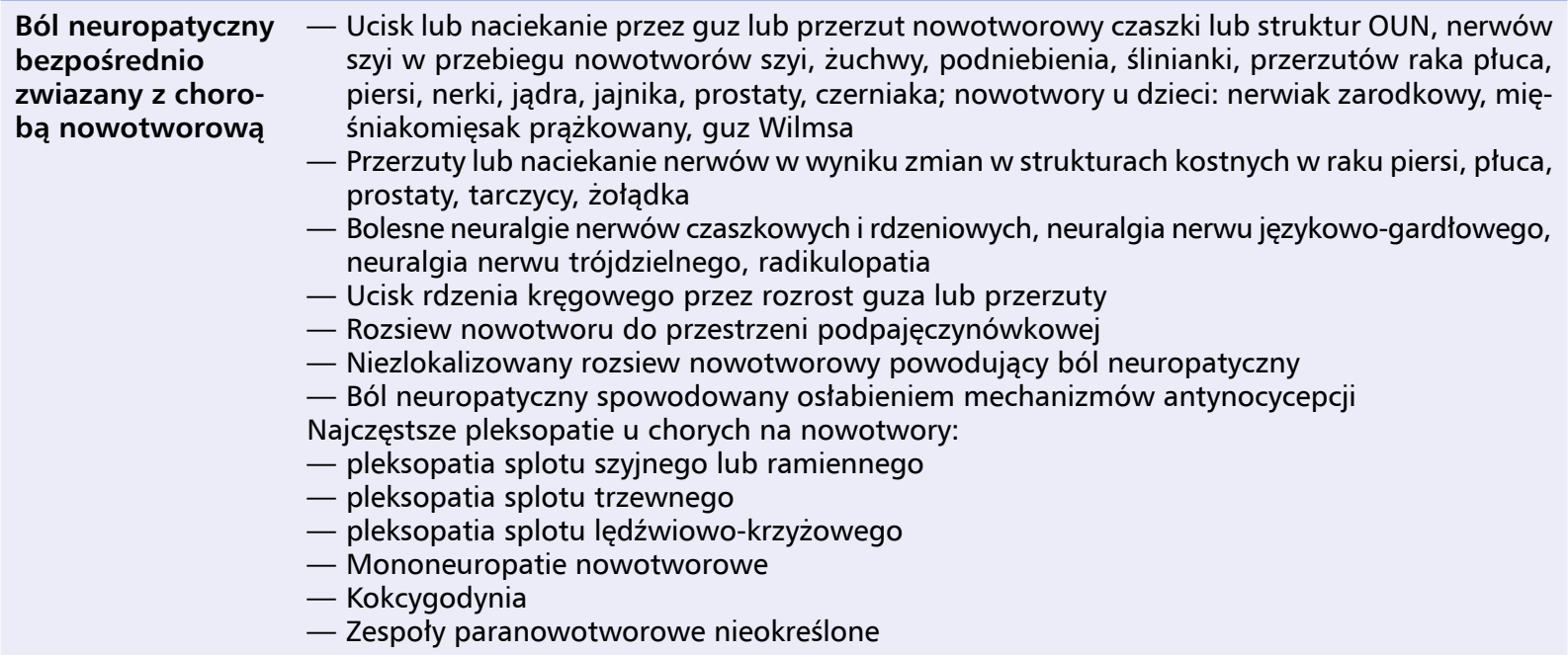

Ból neuropatyczny Zespoły przetrwałego bólu pooperacyjnego: ból neuropatyczny po torakotomii, ból neuwywołany leczeniem przeciwnowotworowym ropatyczny po mastektomii, ból neuropatyczny po operacji w nadbrzuszu, ból fantomowy po amputacji kończyn lub innych struktur ciała

Ból neuropatyczny po radioterapii: ból neuropatyczny w wyniku radioterapii splotu barkowego - popromienna neuropatia splotu barkowego, mielopatia popromienna, bolesny obrzęk limfatyczny popromienny

Ból neuropatyczny po chemioterapii: pochodne platyny, alkaloidy vinca, taksany, bortezomid, talidomid; ból neuropatyczny po długotrwałym leczeniu hormonalnym; ból neuropatyczny wywołany antyestrogenami (tamoksyfen) i inhibitorami aromatazy (anastrozol, letrozol, eksemestan); ból neuropatyczny po zastosowaniu hematopoetycznych czynników wzrostu (HGF, hematopoietic growth actors); ból neuropatyczny po podaniu czynników stymulujących kolonie granulocytów (G-CSF, granulocyte colony-stimulating factors); ból neuropatyczny w wyniku martwicy żuchwy spowodowany leczeniem bisfosfonianami; ból neuropatyczny towarzyszący leczeniu immunomodulującemu

Ból neuropatyczny Zakażenia herpes zoster, jako przyczyna neuralgii popółpaśćcowej

pośrednio zwiąNeurologiczne powikłania w przebiegu sepsy

zany z chorobą Neuropatia obwodowa stopy spowodowana zakażeniem nowotworowa Ból neuropatyczny związany z deficytem immunologicznym bez lokalizacji nowotworu

tosowania od 2021 roku, ujęto dokładną miedzynarodową klasyfikację bólu przewlekłego, w tym bólu neuropatycznego i bólu nowotworowego [29, 30]. Do czasu opublikowania nowych europejskich zapisów bólu neuropatycznego, nadal obowiązuje rozpoznanie objawowe bólu R52. Przyczyny bólu neuropatycznego u chorych na nowotwory przedstawiono w tabeli 1.

\section{Farmakoterapia bólu neuropatycznego}

W 2005 roku IASP opracowało zalecenia leczenia farmakologicznego bólu neuropatycznego opracowane według zasad medycyny opartej na faktach (EBM, evidence-based medicine). W 2006 roku ukazały się zalecenia European Federation of Neurological Societies, w których oprócz skuteczności działania leków, uwzględniono dane dotyczące jakości życia, wpływu leczenia na sen i znaczenia chorób współistniejących. W kolejnych latach opublikowano liczne zalecenia leczenia bólu neuropatycznego [1, 14, 15,
31]. W 2007 roku opracowano zalecenia leczenia bólu neuropatycznego u chorych z bólem przewlekłym nienowotworowym, które z kolejnymi aktualizacjami obejmują:

I. Leczenie objawowe należy poprzedzić rozpoznaniem przyczyny bólu neuropatycznego i podjęciem odpowiedniego leczenia przyczynowego, jeżeli jest możliwe.

II. Przed rozpoczęciem leczenia należy rozpoznać choroby współistniejące, w tym depresję, choroby serca lub nerek, które mogą stanowić przeciwwskazanie leczenia lub wymagają zmiany dawek leków przeciwbólowych.

III. Chorych należy poinformować o rozpoznaniu i planie leczenia oraz realistycznych celach i realnie oczekiwanej skuteczności terapii.

IV. Leczenie bólu neuropatycznego należy prowadzić zgodnie $z$ aktualnymi zaleceniami.

V. Leki pierwszego wyboru w leczeniu bólu neuropatycznego: 
- leki przeciwdrgawkowe: pregabalina lub gabapentyna;

- leki przeciwdepresyjne inhibitory wychwytu zwrotnego serotoniny i noradrenaliny.

VI. Leki drugiego wyboru:

— trójpierścieniowe leki przeciwdepresyjne (amitryptylina);

- lidokaina stosowana miejscowo;

- kapsaicyna stosowana miejscowo.

VII. Leki trzeciego wyboru:

- opioidowe leki przeciwbólowe lub rotacja, jeżeli były uprzednio stosowane.

VIII. Leki czwartej linii:

- kanabinoidy, metadon, karbamazepina ( $z$ wyjątkiem neuralgii nerwu trójdzielnego, w której jest lekiem pierwszego wyboru) i inne leki przeciwpadaczkowe.

W leczeniu bólu neuropatycznego u chorych na nowotwory postępowaniem z wyboru jest stosowanie analgetyków opiodowych zgodnie z drabiną analgetyczną WHO. Opiody stanowią więc pierwszą linię farmakoterapii u chorych na nowotwory z bólem neuropatycznym o umiarkowanym lub silnym natężeniu.

\section{Zalecenia leczenia farmakologicznego bólu neuropatycznego}

- Jeżeli leczenie pierwszego wyboru jest skuteczne (uzyskano zmniejszenie natężenia bólu o co najmniej 50\%), powinno być kontynuowane.

- Jeżeli skuteczność nie jest zadowalająca, należy dodać kolejny lek pierwszej linii o innym mechanizmie działania; jeżeli lek pierwszego wyboru jest nieskuteczny, należy go zmienić na inny lek pierwszej linii.

- Brak skuteczności leków pierwszego wyboru stosowanych pojedynczo lub w połączeniu (w odpowiednich dawkach) stanowi wskazanie terapii lekami drugiej i trzeciej linii.

- W terapii bólu neuropatycznego i bólu trudnego do leczenia u chorych na nowotwory stosowane adjuwanty analgetyczne są dodawane do opioidów.

- Leczenie farmakologiczne, o ile możliwe, powinno być uzupełnione postępowaniem niefarmakologicznym.

- Należy często oceniać skuteczność i tolerancję (działania niepożądane) leczenia.

W leczeniu bólu neuropatycznego u chorych na nowotwory często (u ponad $80 \%$ pacjentów) stosowane są adjuwanty analgetyczne z wykorzystaniem synergii addycyjnej (zwiększenia efektu przeciwbólowego leków o różnych mechanizmach działania)
[32-35]. Leczenie bólu neuropatycznego u chorych na nowotwory wymaga ostrożności, ponieważ stosowanych jest wiele leków z różnych grup: gabapentynoidy (pregabalina, gabapentyna), inhibitory wychwytu zwrotnego serotoniny i noradrenaliny (duloksetyna, wenlafaksyna), leki przeciwdrgawkowe (karbamazepina, okskarbazepina, kwas walproinowy), trójpierścieniowe leki przeciwdepresyjne (amitryptylina), opioidy, kanabinoidy i leki o działaniu miejscowym (kapsaicyna, lidokaina) [36]. Stosowane są również leki miorelaksujące, przeciwlękowe, kortykosteroidy, środki anestetyczne (ketamina), metody interwencyjne, fizykoterapia i psychoterapia [21, 37]. U chorych z bólem neuropatycznym wyróżniono leczenie pierwszej, drugiej, trzeciej i czwartej linii.

Gabapentynoidy są lekami pierwszej linii w leczeniu bólu neuropatycznego u chorych z bólem nienowotworowym [38]. W leczeniu farmakologicznym neuralgii nerwu trójdzielnego nadal zalecana jest karbamazepina i pochodne, jako leki pierwszej linii [39-41]. Pomocniczo w farmakoterapii bólu neuropatycznego, w przypadku niedoboru, stosuje się witaminy z grupy B. Leczenie bólu neuropatycznego jest wielokierunkowe i obejmuje również metody niefarmakologiczne i interwencyjne. W wielu przypadkach stosowane są blokady nerwów i neurolizy hamujące przewodzenie bólu [41]. Istotnym elementem terapii jest usprawnianie pacjenta i fizykoterapia, które znacząco hamują postęp choroby $[22,24]$.

\section{Gabapentyna}

Gabapentyna pod względem budowy chemicznej jest podobna do kwasu gamma-aminomasłowego (GABA) (ryc. 1) [39]. Mechanizm działania różni się od mechanizmu działania innych substancji czynnych wchodzących w interakcję z synapsami GABA-ergicznymi: walproinianu, barbituranów, benzodiazepin, inhibitorów transaminazy GABA, inhibitorów wychwytu GABA, agonistów GABA i proleków GABA [40]. Badania in vitro, w których wykorzystywano znakowaną gabapentynę, scharakteryzowały peptydowe miejsce wiązania w tkance mózgowej, między innymi w obrębie kory nowej i hipokampa, co może być związane z działaniem przeciwdrgawkowym i przeciwbólowym gabapentyny i jej pochodnych strukturalnych [40]. Miejsce wiązania gabapentyny zidentyfikowano w obrębie podjednostki alfa-2-delta kanałów wapniowych bramkowanych napięciem. Gabapentyna nie wiąże się z receptorami GABA-A, GABA-B, benzodiazepinowy, receptor dla glutaminianu, glicyny i N-metylo-D-asparaginianu (NMDA).

W warunkach in vitro, w odróżnjeniu od innych leków przeciwdrgawkowych (fenytoiny, karbamazepi- 


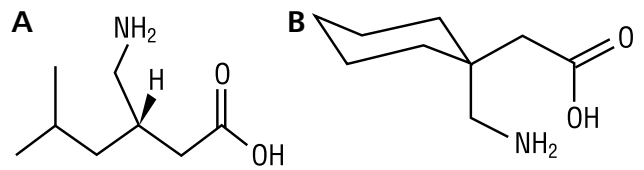

Rycina 1. Wzory strukturalne gabapentynoidów. A. Pregabalina. B. Gabapentyna. Pregabalinę cechuje prosta struktura chemiczna z mniejszą liczbą atomów węgla w odprowadzeniu bocznym

na), gabapentyna nie wchodzi w interakcje z kanałami sodowymi [39]. W badaniach eksperymentalnych gabapentyna częściowo osłabia reakcje na agonistę glutaminianu NMDA, jednak tylko w stężeniach powyżej $100 \mu \mathrm{M}$, których w warunkach in vivo nie osiąga się. Gabapentyna nieznacznie zmniejsza uwalnianie neurotransmiterów monoaminowych w warunkach in vitro. Podawanie gabapentyny zwiększa obrót GABA w kilku obszarach mózgu w sposób podobny do walproinianu sodu, choć w innych regionach. Znaczenie opisanych kierunków działań gabapentyny dla efektu przeciwdrgawkowego pozostaje nieustalone. Oprócz działania przeciwdrgawkowgo efekt analgetyczny w leczeniu bólu neuropatycznego został opisany w charakterystyce produktów leczniczych i zarejestrowany dla niektórych produktów do stosowania przez pacjentów ubezpieczenia zdrowotnego w Polsce.

Dawkowanie gabapentyny w obwodowym bólu neuropatycznym wymaga stopniowego zwiększania dawek. Leczenie można rozpocząć od podania $300 \mathrm{mg}$ raz/dobę lub od dawki 900 mg/dobę w trzech równych dawkach podzielonych. Następnie, w zależności od indywidualnej odpowiedzi i tolerancji leczenia, dawkę można zwiększać o 300 mg/dobę, co 2-3 dni do maksymalnej dawki 3600 mg/dobę. Minimalny czas do osiągnięcia dawki 1800 mg/dobę wynosi 7 dni, do dawki 2400 mg/dobę 14 dni, do dawki 3600 mg/dobę 21 dni. U chorych w podeszłym wieku i z chorobą nerek lub dializowanych konieczna jest modyfikacja dawki leku.

\section{Pregabalina}

Pregabalina należy do względnie nowych leków aktywnych wobec neuronów pobudzających i hamujących [42]. Lek zsyntetyzowano w amerykańskim laboratorium w 1990 roku jako następcę gabapentyny. Warto podkreślić, że wkład w powstanie związku miał Polak - pracownik naukowy laboratorium, Ryszard Andruszkiewicz [43]. Pregabalina jest pochodną i analogiem GABA, jednak działa odmiennie od leków GABA-ergicznych. Budową przypomina $\alpha$-aminokwasy naturalnie wystepujące w OUN: L-leucynę i L-izoleucynę, struktura chemiczna leku nieznacznie różni się od gabapentyny (ryc. 2). Pregabalina działa poprzez hamowanie niektórych kanałów wapniowych, nie będąc agonistą receptorów GABA [44]. Lek jest ligandem zależnym od napięcia kanałów wapniowych VGCC (voltage gated calcium channels) i inhibitorem VGCC zawierającym podjednostki: $\alpha 2 \delta$-1 i $\alpha 2 \delta$-2. Pomimo że pregabalina jest analogiem GABA, nie wiąże się $z$ receptorami GABA, nie przekształca się w GABA ani $w$ innego agonistę receptora GABA in vivo i nie moduluje bezpośrednio transportu ani metabolizmu GABA. Pregabalina powoduje wzrost dekarboksylazy kwasu L-glutaminowego (GAD), enzymu odpowiedzialnego za syntezę GABA, a zatem może wykazywać pośrednie efekty GABA-ergiczne [45].

Działanie pregabaliny na kanały wapniowe VGCC jest odpowiedzialne za działanie przeciwdrgawkowe, przeciwbólowe i przeciwlękowe. W porównaniu z gabapentyną, pregabalina wykazuje większe powinowactwo do kanałów VGCC i 4-krotnie silniejszy efekt przeciwbólowy, w badaniach eksperymentalnych przeprowadzonych na zwierzętach 10-krotnie silniejszy efekt przeciwdrgawkowy [46]. Lek zarejestrowano w 2004 roku w Europie i w Stanach Zjednoczonych do leczenia wspomagającego padaczki u dorosłych z napadami częściowymi, leczenia neuralgii popółpaśćcowej, bólu neuropatycznego (w obrazie klinicznym - ból piekący, rwący, ostry i przeszywający), obwodowej polineuropatii cukrzycowej i w leczeniu uogólnionych zaburzeń lękowych [47].

Pregabalina jest zalecana przez Europejską Federację Towarzystw Neurologicznych, jako lek pierwszej linii w leczeniu bólu związanego z neuropatią cukrzycową, neuralgii po przebytym półpaśćcu i ośrodkowym bólu neuropatycznym [48], w powyższych wskazaniach została zarejestrowana, może być jednak stosowana również w leczeniu innych rodzajów bólu neuropatycznego. Pregabalina zmniejsza nadmierną pobudliwość neuronalną, łagodzi ból neuropatyczny po osiągnięciu stabilnych stężeń w osoczu po zaledwie kilku dniach [49]. Ze względu na prostą budowę cząsteczki, w odróżnieniu od gabapentyny, jest skuteczna zarówno w bólu neuropatycznym ośrodkowym, jak i w neuropatiach obwodowych w przebiegu chorób kręgosłupa, miażdżycy tętnic, chorobach hematologicznych, reumatologicznych, infekcyjnych i zakaźnych — borelioza i HIV (human imunodeficiency virus). Pożądanym działaniem jest zastosowanie leku w neuropatiach jatrogennych, w tym pooperacyjnych i polekowych [50]. Lek można stosować w leczeniu bólu w przebiegu neuropatii wywołanej cytostatykami podawanymi w leczeniu nowotworów, lekami przeciwgruźliczymi i przeciwpadaczkowymi oraz w zatruciu ołowiem, alkoholem i niedoborach żywieniowych [49]. 


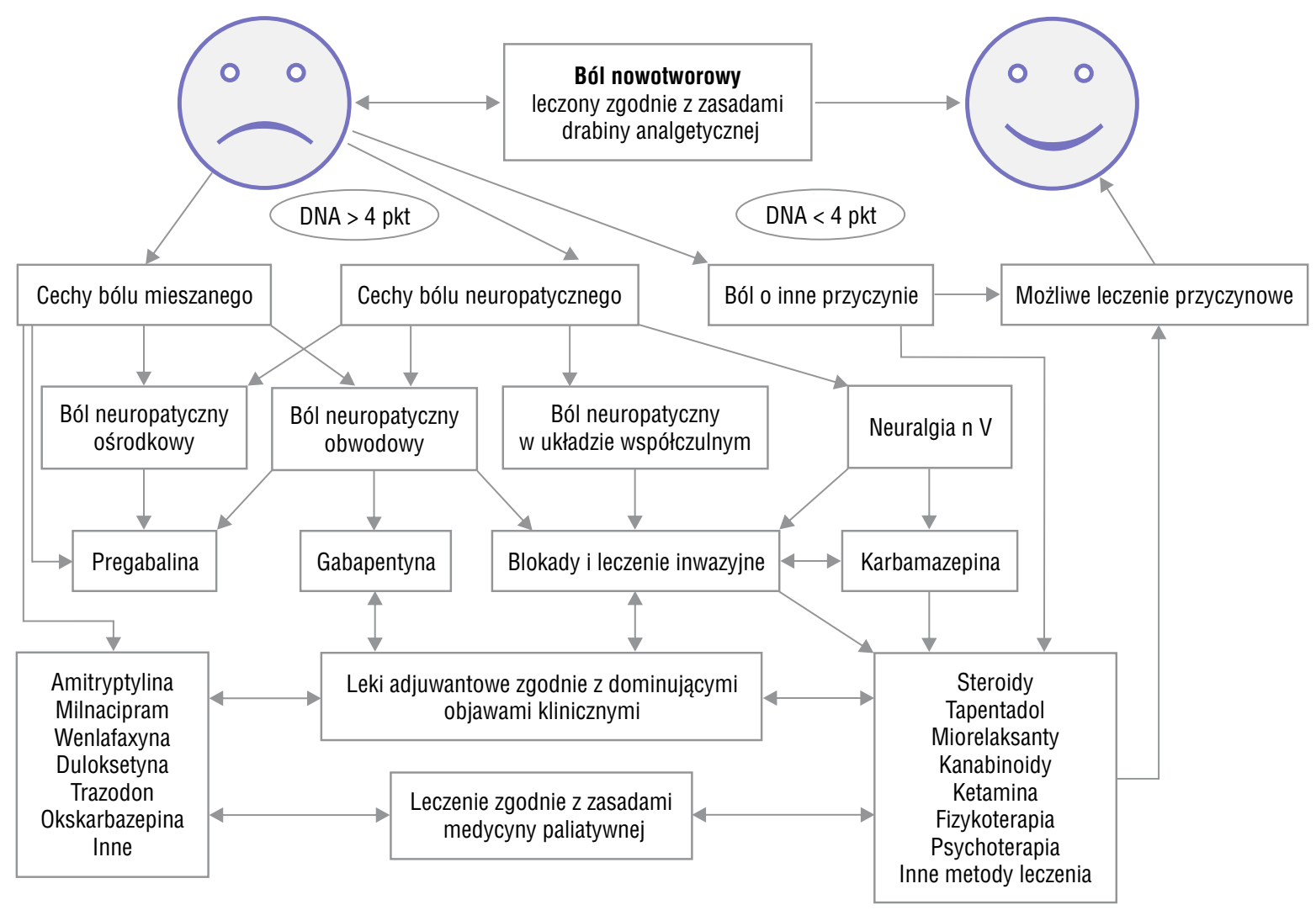

Rycina 2. Algorytm diagnostyki i leczenia bólu neuropatycznego u chorych na nowotwory

Biodostępność pregabaliny po podaniu drogą doustną wynosi ponad 90\%,w zakresie dawek klinicznych 50-600 mg/dobę. Spożycie pokarmu nie wpływa znacząco na biodostępność pregabaliny. Lek w niewielkim stopniu podlega metabolizmowi, lek jest wydalany w postaci niezmienoonej w około $98 \%$ z moczem. Ze względu na fakt, że klirens pregabaliny jest wprost proporcjonalny do klirensu kreatyniny, dawki u pacjentów z zaburzeniami czynności nerek powinny zostać zmniejszone indywidualnie.

Leczenie bólu neuropatycznego można rozpocząć od dawki 150 mg/dobę, podawanej w dwóch lub rzadziej trzech dawkach podzielonych. W zależności od indywidualnej reakcji pacjenta i tolerancji leczenia, po 3-7 dniach dawkę można zwiększyć do 300 mg/dobę, a następnie w zależności od potrzeby, po kolejnych 7 dniach do maksymalnej dawki 600 mg/dobę [35, 50]. U chorych z niewydolnością nerek i starszych pacjentów dawki leku mogą być mniejsze, zwykle wynoszą początkowo 25-75 mg/dobę.

Stosowanie pregabaliny w bólu neuropatycznym u chorych na nowotwory jest zalecane w kilku systemach zdrowotnych, także w Polsce [28, 31, 49]. Brak dowodów na skuteczność leku w zapobieganiu migreny, chociaż takie zastosowanie również zostało opisane [29]. Nadzieję budzi potencjalne zastosowa- nie pregabaliny w zapobieganiu przetrwałego bólu po zabiegach chirurgicznych. Pregabalinę stosuje się zwłaszcza kiedy inne metody są nieskuteczne, w leczeniu napadów padaczkowych częściowych u osób dorosłych, które są (lub nie) wtórnie uogólnione. Leczenie można rozpocząć od dawki 150 mg/dobę, podawanej w dwóch lub trzech dawkach podzielonych, stopniowo zwiększanych, w zależności od indywidualnej reakcji i tolerancji leczenia, do $300 \mathrm{mg} /$ dobę, ewentualnie do dawki maksymalnej 600 mg/dobę.

Bardzo interesujące są próby zastosowania pregabaliny w uzależnieniu od alkoholu, zwłaszcza w zespołach abstynencyjnych i towarzyszących drgawkach [46]. Dowody na korzyść w leczeniu uzależnienia od alkoholu są ograniczone, natomiast w zespole odstawiennym jest stosowana z powodzeniem, chociaż wskazanie nie jest objęte rejestracją leku. Pregabalina jest również skuteczna i bezpieczna w leczeniu uogólnionych zaburzeń lękowych. Światowa Federacja Psychologii Biologicznej zaleca pregabalinę jako jedną z metod leczenia uogólnionych zaburzeń lękowych i jako leczenie pierwszej linii zaburzeń obsesyjno-kompulsywnych i zespołu stresu pourazowego. Działanie przeciwlękowe jest podobne do benzodiazepin z mniejszym ryzykiem rozwoju uzależnienia [46]. Poza leczeniem bólu neuropatycznego i zespołu lęku 
uogólnionego u dorosłych pozarejestracyjne stosowanie pregabaliny obejmuje fibromialgię, lęk społeczny, zespół odstawienny poalkoholowy i lęk towarzyszący napadom migreny w okresie aury [24].

Działanie przeciwlękowe pregabaliny pojawia się po 7 dniach leczenia i jest podobnie skuteczne jak lorazepamu, alprazolamu i wenlafaksyny, jednak pregabalina jest skuteczniejsza w leczeniu objawów lęku psychosomatycznego. Długotrwałe badania wykazały stałą skuteczność bez rozwoju tolerancji, w przeciwieństwie do benzodiazepin, korzystny wpływ na architekturę snu, charakteryzującą się nasileniem snu wolnofalowego. W porównaniu z benzodwuazepinami pregabalina powoduje mniej zaburzeń funkcji poznawczych i psychomotorycznych i małe ryzyko uzależnienia. Istotna niekorzystna interakcja zachodzi pomiędzy pregabaliną a lorazepamem, która występuje na poziomie sprzęgania i powoduje znaczne nasilenie sedacji. W uogólnionych zaburzeniach lękowych zalecana jest dawka $150 \mathrm{mg}$ podawana wieczorem [51]. Dawka terapeutyczna wynosi 150-600 mg/dobę podawana w dwóch lub trzech dawkach podzielonych. Należy regularnie oceniać rekację na leczenie i konieczność jego kontynuacji.

Do działań niepożądanych, związanych ze stosowaniem pregabaliny, należą najczęściej zawroty głowy i senność. Około 1-10\% pacjentów zgłasza suchość w ustach, zwiększony apetyt, osłabienie, niewyraźne widzenie, splątanie, zaburzenia uwagi i koordynacji, zaparcia, obrzęki obwodowe, zmniejszoną tolerancję alkoholu. U 0,1-1\% pacjentów wystepuje: depresja, letarg, pobudzenie, omamy, mioklonie, niedoczulica, przeczulica, tachykardia, nadmierne ślinienie, hipoglikemia, pocenie, zaczerwienienie, wysypka, bóle mięśni, dyzuria i małopłytkowość [52].

Po nagłym odstawieniu pregabaliny może wystąpić bezsenność, bóle głowy, nudności, lęk, biegunka, objawy grypopodobne. Amerykańska Agencja Żywności i Leków (FDA, Food and Drug Administration) ustaliła, że profil uzależnienia od pregabaliny, mierzony za pomocą listy kontrolnej wycofania fizycznego pacjenta, jest ilościowo mniejszy niż benzodiazepin. U pacjentów z niewydolnością nerek podczas przyjmowania pregabaliny mogą nasilić się objawy przedawkowania w wyniku stopniowej kumulacji leku [52]. Ostre przedawkowanie może objawiać się sennością, tachykardią i nadciśnieniem. Proponowany algorytm stosowania pregabaliny i gabapentyny w leczeniu bólu neuropatycznego $u$ chorych na nowotwory na podstawie aktualnych zaleceń przedstawiono na rycinie 2 .

\section{Podsumowanie}

W leczeniu bólu u chorych na nowotwory podstawową rolę odgrywają analgetyki opioidowe, a adjuwanty analgetycznae są dodawane do opioidów przy braku zadowalającej analgezji. Istotne jest dostosowanie leczenia do występujących objawów somatycznych i psychicznych. Postępowanie terapeutyczne jest uzależnione od rodzaju bólu (ból neuropatyczny, mieszany wywołany, np. przezrzutami do kości) i występowanie innych objawów (depresja, stany lękowe). $\mathrm{U}$ chorych na nowotwory podstawową zasadą jest leczenie zgodne z trójstopniową drabiną analgetyczną WHO, a rozpoznanie komponenty neuropatycznej bólu jest wskazaniem do rozważenia koanalgetyku, przy braku efektu opioidu. Pregabalina i gabapentyna stanowią leki pierwszej linii $w$ leczeniu bólu neuropatycznego $u$ chorych $z$ bólem nienowotworowym, natomiast u chorych na nowotwory mogą być dodawane do opioidów przy braku zadowalającej analgezji podczas samodzielnego stosowania analgetyków opioidowych.

\section{Deklaracja konfliktu interesów}

Autorzy oświadczają, że nie występuje konflikt interesów.

\section{Finansowanie}

Badanie nie było finansowane.

\section{References}

1. Caraceni A, Hanks G, Kaasa S, et al. Use of opioid analgesics in the treatment of cancer pain: evidence-based recommendations from the EAPC. The Lancet Oncology. 2012; 13(2): e58-e68, doi: 10.1016/s1470-2045(12)70040-2.

2. Edwards HL, Mulvey MR, Bennett MI. Cancer-Related Neuropathic Pain. Cancers (Basel). 2019; 11(3), doi: 10.3390/cancers11030373, indexed in Pubmed: 30884837.

3. Arias-Casais N, Garralda E, Rhee JY, De Li, Pons JJ, Clark D. EAPC Atlas of palliative care in Europe 2019. Vilvoorde: EAPC Press 2019.

4. Ciałkowska-Rysz A, Dzierżanowski T. Podstawowe zasady farmakoterapii bólu u chorych na nowotwory i inne przewlekłe, postępujące, zagrażające życiu choroby. PalliativeMedicine. 2014; 1: 1-6.

5. Dzierżanowski T, Ciałkowska-Rysz A. Ból neuropatyczny u pacjentów objętych opieką paliatywną. Med Paliat. 2010; 2: 57-66.

6. Leppert W. Rola analgetyków opioidowych w leczeniu bólu neuropatycznego u chorych na nowotwory. Medycyna Paliat Prakt. 2014; 8(2): 81-84.

7. Zajączkowska R, Wordliczek J, Leppert W. Mechanizmy i zespoły bólu neuropatycznego u chorych na nowotwór. Med Paliat Prakt. 2014; 8(2): 66-73. 
8. Sumitani M, Sakai T, Matsuda $Y$, et al. Executive summary of the Clinical Guidelines of Pharmacotherapy for Neuropathic Pain: second edition by the Japanese Society of Pain Clinicians. J Anesth. 2018; 32(3): 463-478, doi: 10.1007/s00540018-2501-0, indexed in Pubmed: 29737410.

9. Finnerup NB, Attal N, Haroutounian S, et al. Pharmacotherapy for neuropathic pain in adults: a systematic review and meta-analysis. Lancet Neurol. 2015; 14(2): 162-173, doi: 10.1016/S1474-4422(14)70251-0, indexed in Pubmed: 25575710.

10. Baron R, Maier C, Attal N, et al. Peripheral neuropathic pain: a mechanism-related organizing principle based on sensory profiles. Pain. 2017; 158(2): 261-272, doi: 10.1097/j. pain. 0000000000000753 , indexed in Pubmed: 27893485.

11. Janecki M. Przegląd narzędzi służących do oceny bólu neuropatycznego. Med Paliat Prakt. 2014; 8(2): 74-77.

12. Mathieson $S$, Maher CG, Terwee CB, et al. Neuropathic pain screening questionnaires have limited measurement properties. A systematic review. J Clin Epidemiol. 2015; 68(8): 957-966, doi: 10.1016/j.jclinepi.2015.03.010, indexed in Pubmed: 25895961.

13. Boland EG, Mulvey MR, Bennett MI. Classification of neuropathic pain in cancer patients. Curr Opin Support Palliat Care. 2015; 9(2): 112-115, doi: 10.1097/SPC.0000000000000136, indexed in Pubmed: 25923341.

14. Chaparro LE, Wiffen PJ, Moore RA, et al. Combination pharmacotherapy for the treatment of neuropathic pain in adults. Cochrane Database Syst Rev. 2012(7): CD008943, doi: $10.1002 / 14651858 . C D 008943$. pub2, indexed in Pubmed: 22786518.

15. Szczudlik A, Dobrogowski J, Wordliczek J, et al. Diagnosis and Management of Neuropathic Pain: Review of Literature and Recommendations of the Polish Association for the Study of Pain and the Polish Neurological Society - Part One. Ból. 2014; 15(3): 8-21, doi: 10.5604/1640324x.1117109.

16. Szczudlik A, et al. Rozpoznanie i leczenie bólu neuropatycznego część 2: przegląd piśmiennictwa i zalecenia Polskiego Towarzystwa Badania Bólu i Towarzystwa Neurologicznego. Ból 2014; 15(2): 8-18. PTBB. (www.ptbb.pl).

17. Ciałkowska-Rysz A, Dzierżanowski T. Topical morphine for treatment of cancer-related painful mucosal and cutaneous lesions: a double-blind, placebo-controlled cross-over clinical trial. Arch Med Sci. 2019; 15(1): 146-151, doi: 10.5114/aoms.2018.72566, indexed in Pubmed: 30697265.

18. Wordliczek J, Zajączkowska R, Leppert W. Pharmacotherapy of neuropathic pain. Med Paliat Prakt. 2017; 11(2): 61-73.

19. Ciałkowska-Rysz A, Dzierżanowski T. Ból neuropatyczny u pacjenta z naciekiem nowotworowym okolicy lędźwiowo-krzyżowej - opis przypadku. Med Paliat. 2012; 4: 229-231.

20. Moulin D, Boulanger A, Clark AJ, et al. Canadian Pain Society. Pharmacological management of chronic neuropathic pain: revised consensus statement from the Canadian Pain Society. Pain Res Manag. 2014; 19(6): 328-335, doi: 10.1155/2014/754693, indexed in Pubmed: 25479151.

21. Fallon M, Giusti R, Aielli F, et al. ESMO Guidelines Committee. Electronic address: clinicalguidelines@esmo.org, ESMO Guidelines Committee. Management of cancer pain in adult patients: ESMO Clinical Practice Guidelines. Ann Oncol. 2018; 29(Suppl 4): iv166-iv191, doi: 10.1093/annonc/mdy152, indexed in Pubmed: 30052758.

22. Rayment $\mathrm{C}$, Hjermstad MJ, Aass N, et al. European Palliative Care Research Collaborative (EPCRC). Neuropathic cancer pain: prevalence, severity, analgesics and impact from the European Palliative Care Research Collaborative-Computerised Symptom Assessment study. Palliat Med. 2013; 27(8):
714-721, doi: 10.1177/0269216312464408, indexed in Pubmed: 23175513.

23. Attal N. Neuropathic Pain Special Interest Group of the International Association for the Study of Pain. Management of neuropathic cancer pain. Ann Oncol. 2010; 21(5): 1134-1135, doi: 10.1093/annonc/mdq031, indexed in Pubmed: 20147740.

24. Oosterling A, te Boveldt N, Verhagen C, et al. Neuropathic Pain Components in Patients with Cancer: Prevalence, Treatment, and Interference with Daily Activities. Pain Pract. 2016; 16(4): 413-421, doi: 10.1111/papr.12291, indexed in Pubmed: 25857631.

25. Bennett MI, Kaasa S, Barke A, et al. IASP Taskforce for the Classification of Chronic Pain. The IASP classification of chronic pain for ICD-11: chronic cancer-related pain. Pain. 2019; 160(1): 38-44, doi: 10.1097/j. pain. 0000000000001363 , indexed in Pubmed: 30586069.

26. Finnerup NB, Haroutounian S, Kamerman P, et al. Neuropathic pain: an updated grading system for research and clinical practice. Pain. 2016; 157(8): 1599-1606, doi: 10.1097/j. pain. 0000000000000492 , indexed in Pubmed: 27115670.

27. The International Classification of Diseases, Tenth Revision, Clinical Modification. 2020 edition of ICD-10-CM, American Medical Association 2020. https://www.cdc. $\mathrm{gov} / \mathrm{nchs} / \mathrm{icd} / \mathrm{icd} 10 \mathrm{~cm} . \mathrm{htm}$. (The 2020 edition of ICD10-CM became effective on 1 October 2019).

28. Scholz J, Finnerup NB, Attal N, et al. Classification Committee of the Neuropathic Pain Special Interest Group (NeuPSIG). The IASP classification of chronic pain for ICD-11: chronic neuropathic pain. Pain. 2019; 160(1): 53-59, doi: 10.1097/j.pain.0000000000001365, indexed in Pubmed: 30586071

29. Bennett MI, Kaasa S, Barke A, et al. IASP Taskforce for the Classification of Chronic Pain. The IASP classification of chronic pain for ICD-11: chronic cancer-related pain. Pain. 2019; 160(1): 38-44, doi: 10.1097/j. pain. 0000000000001363 , indexed in Pubmed: 30586069.

30. Finnerup NB, Sindrup SH, Jensen TS. The evidence for pharmacological treatment of neuropathic pain. Pain. 2010; 150(3): 573-581, doi: 10.1016/j.pain.2010.06.019, indexed in Pubmed: 20705215.

31. Yoon SoY, Oh J. Neuropathic cancer pain: prevalence, pathophysiology, and management. Korean J Intern Med. 2018; 33(6): 1058-1069, doi: 10.3904/kjim.2018.162, indexed in Pubmed: 29929349.

32. Mercadante S, Klepstad P, Kurita GP, et al. European Palliative Care Research Collaborative (EPCRC). Sympathetic blocks for visceral cancer pain management: A systematic review and EAPC recommendations. Crit Rev Oncol Hematol. 2015; 96(3): 577-583, doi: 10.1016/j.critrevonc.2015.07.014, indexed in Pubmed: 26297518.

33. Colloca L, Ludman T, Bouhassira D, et al. Neuropathic pain. Nat Rev Dis Primers. 2017; 3: 17002, doi: 10.1038/nrdp.2017.2, indexed in Pubmed: 28205574.

34. Kane CM, Mulvey MR, Wright S, et al. Opioids combined with antidepressants or antiepileptic drugs for cancer pain: Systematic review and meta-analysis. Palliat Med. 2018; 32(1): 276-286, doi: 10.1177/0269216317711826, indexed in Pubmed: 28604172.

35. Woroń J, Adamczyk A, Malec-Milewska M, et al. Stosowanie koanalgetyków u pacjentów z bólem neuropatycznym w przebiegu choroby nowotworowej. Med Paliat Prakt 2014; 8. 2014; 8(2): 85-90.

36. Kotlinska-Lemieszek A, Klepstad P, Haugen DF. Clinically significant drug-drug interactions involving opioid analgesics used for pain treatment in patients with cancer: a systematic review. Drug Des Devel Ther. 2015; 9: 5255-5267, doi: 10.2147/DDDT.S86983, indexed in Pubmed: 26396499. 
37. Mercadante S, Caruselli A, Casuccio A. The use of ketamine in a palliative-supportive care unit: a retrospective analysis. Ann Palliat Med. 2018; 7(2): 205-210, doi: 10.21037/apm.2018.01.01, indexed in Pubmed: 29764182.

38. Uchitel OD, Di Guilmi MN, Urbano FJ, et al. Acute modulation of calcium currents and synaptic transmission by gabapentinoids. Channels (Austin). 2010; 4(6): 490-496, doi: 10.4161/chan.4.6.12864, indexed in Pubmed: 21150315.

39. Jordan RI, Mulvey MR, Bennett MI. A critical appraisal of gabapentinoids for pain in cancer patients. Curr Opin Support Palliat Care. 2018; 12(2): 108-117, doi: 10.1097/SPC.0000000000000337, indexed in Pubmed: 29465469.

40. Slee A, Nazareth I, Bondaronek P, et al. Pharmacological treatments for generalised anxiety disorder: a systematic review and network meta-analysis. Lancet. 2019; 393(10173): 768-777, doi: 10.1016/50140-6736(18)31793-8, indexed in Pubmed: 30712879.

41. Wordliczek J, Kotlińska-Lemieszek A, Leppert W, et al. Farmakoterapia bólu u chorych na nowotwory - zalecenia Polskiego Towarzystwa Badania Bólu, Polskiego Towarzystwa Medycyny Paliatywnej, Polskiego Towarzystwa Onkologicznego, Polskiego Towarzystwa Medycyny Rodzinnej i Polskiego Towarzystwa Anestezjologii i Intensywnej Terapii. Pain. 2017; 18(3): 11-53.

42. Andruszkiewicz R, Silverman RB. 4-Amino-3-alkylbutanoic acids as substrates for gamma-aminobutyric acid aminotransferase. J Biol Chem. 1990; 265(36): 22288-22291, indexed in Pubmed: 2266125.

43. Linde M, Mulleners W, Chronicle E, et al. Gabapentin or pregabalin for the prophylaxis of episodic migraine in adults. Cochrane Database of Systematic Reviews. 2013; 6(6): CD010609, doi: 10.1002/14651858.cd010609.

44. Bennett MI, Laird B, van Litsenburg C, et al. Pregabalin for the management of neuropathic pain in adults with cancer: a systematic review of the literature. Pain Med. 2013; 14(11): 1681-1688, doi: 10.1111/pme.12212, indexed in Pubmed: 23915361.
45. Bockbrader HN, Wesche D, Miller R, et al. A comparison of the pharmacokinetics and pharmacodynamics of pregabalin and gabapentin. Clin Pharmacokinet. 2010; 49(10): 661-669, doi: 10.2165/11536200-000000000-00000, indexed in Pubmed: 20818832.

46. Frampton JE. Pregabalin: a review of its use in adults with generalized anxiety disorder. CNS Drugs. 2014; 28(9): 835-854, doi: 10.1007/s40263-014-0192-0, indexed in Pubmed: 25149863.

47. Wensel TM, Powe KW, Cates ME. Pregabalin for the treatment of generalized anxiety disorder. Ann Pharmacother. 2012; 46(3): 424-429, doi: 10.1345/aph.1Q405, indexed in Pubmed: 22395254.

48. Derry $S$, Bell RF, Straube $S$, et al. Pregabalin for neuropathic pain in adults. Cochrane Database Syst Rev. 2019; 1: CD007076, doi: 10.1002/14651858.CD007076.pub3, indexed in Pubmed: 30673120.

49. Onakpoya IJ, Thomas ET, Lee JJ, et al. Benefits and harms of pregabalin in the management of neuropathic pain: a rapid review and meta-analysis of randomised clinical trials. BMJ Open. 2019; 9(1): e023600, doi: 10.1136/bmjopen-2018-023600, indexed in Pubmed: 30670513.

50. de Andrade DC, Jacobsen Teixeira M, Galhardoni R, et al. PreOx Workgroup. Pregabalin for the Prevention of Oxaliplatin-Induced Painful Neuropathy: A Randomized, Double-Blind Trial. Oncologist. 2017; 22(10): 1154-e105, doi: 10.1634/theoncologist.2017-0235, indexed in Pubmed: 28652279

51. Gül ŞK, Tepetam H, Gül HL. Duloxetine and pregabalin in neuropathic pain of lung cancer patients. Brain Behav. 2020; 10(3): e01527, doi: 10.1002/brb3.1527, indexed in Pubmed: 31967742.

52. Yajima R, Matsumoto $K$, Ise $Y$, et al. Pregabalin prescription for terminally ill cancer patients receiving specialist palliative care in an acute hospital. J Pharm Health Care Sci. 2016; 2: 29, doi: 10.1186/s40780-016-0063-6, indexed in Pubmed: 27826454. 